\title{
The Sarbanes-Oxley Act And German Non-Profit Organizations: An Empirical Investigation
}

\author{
Thomas Wilhelm Hasenpflug, Edinburgh Business School, Germany
}

\begin{abstract}
Drawing on a survey of German non-profit organizations, this paper explores the state of implementation of corporate governance mechanisms by focusing on the organizations' profiles. Subject of the research are those mechanisms as developed in the 2002 Sarbanes-Oxley Act for the for-profit sector which have since also been implemented for non-profit sector organizations. In applying chi-square tests, the association between the existence of these practices and a range of organizational characteristics was reviewed and the most influential characteristics were identified. This association of characteristics and practices explains a potential compliance of an organization. Such knowledge can be applied by a number of stakeholder groups, such as organizational decision-makers, legislators and sponsors. The identified characteristics, in order of importance, were annual revenue, age of the organization, existence of an international branch structure, organizations' board members being active in the private sector, and organizations having an international scope of activities.
\end{abstract}

Keywords: Corporate Governance; Non-profit Sector; Sarbanes-Oxley Act; Germany

\section{INTRODUCTION}

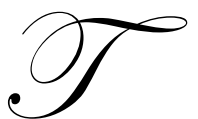

he 2002 Sarbanes-Oxley Act was enacted to address the specific causes of highly publicized scandals at a number of well-known US publicly traded companies at that time. Nevertheless, an immediate impact of the new law was also felt in the US non-profit sector where large organizations were first recommended, later mandated to implement corporate governance mechanisms similar to those adopted in the forprofit sector.

Recognizing the pressures felt by non-profit leaders to consider the changes and developments brought on by SOA, it is important to assess how far non-profit organizations are already prepared to comply with practices modelled on the provisions of the Act.

Research and resulting debates concerning the US non-profit sector have already been going on for some time (Ostrower and Bobowick, 2006, and Nezhina and Brudney, 2009), but influence on the non-profit sector in other industrialized countries can also be expected. In that regard, this paper is a contribution to that debate, focusing on the non-profit sector in Germany, and further research and debate are necessary concerning these countries.

Specifically, this research examines an association between the preparedness for compliance with the provisions of the Act to the organizations' characteristics. The goal is to identify those characteristics which are most influential by displaying a significant association to high levels of preparedness.

Among those organizational characteristics identified are the annual revenue of the organization and its age, the existence of an international branch or sub-organizational structure, and the organization having an international scope of activities. An organization's board members being active in the private sector was also found to be of note. 
Knowledge about these influential characteristics can be used by organizational stakeholders in relation to matters of compliance. Organizational leaders, regulators, as well as donors and sponsors, are the main beneficiaries of the research findings. Further, consultants and services providers to the sector, as well as auditors, are also concerned.

In the following, first the Sarbanes-Oxley Act and its impact on the non-profit sector is introduced, including the specific identification of those measures of the Act which are important for sector entities. A brief description of the German non-profit sector and its particular corporate governance background leads to the definition of the organizational characteristics subject of the investigation.

After developing the research question, the research methodology and data analysis are laid-out. Here, specifics concerning each of the data collection methods - mail survey, interviews and documentary investigation are discussed.

This paper concludes with the recommendations for each of the defined groups of non-profit sector stakeholders and the ways of application of the research findings.

\section{THE SARBANES-OXLEY ACT AND ITS IMPACT ON THE NON-PROFIT SECTOR}

In 2002, the United States Congress passed the 'Public Company Accounting Reform and Investor Protection Act' - short-titled 'the Sarbanes-Oxley Act of 2002' (SOA) - to 'protect investors by improving the accuracy and reliability of corporate disclosures' (US Congress, 2002).

The implementation of the Act's provisions has had a profound impact on publicly traded companies; in fact, corporate governance practices in most US companies were subsequently affected by the demands laid down here (Budak, 2003; Schuerman, 2004; Romano, 2005; Zhang, 2005; Iliev, 2007). Foreign companies listed in the US or operating subsidiaries there, as well as the overseas subsidiaries of US-based corporations, were likewise subjected to these changes thus adding an international dimension to the impact of the new law (von der Crone and Roth, 2003; Shirley, 2004; Iliev, 2007; Litvak, 2007; Menden and Kralisch, 2008; Piotroski and Srinivansan, 2008).

Whereas SOA was specifically aimed only at the for-profit sector, its passage immediately set off a debate whether non-profit entities should not be held accountable to the same or similar standard. It was put forth that certain provisions should also be mandated for the non-profit sector or at least be followed voluntarily as a matter of best practices (Heinz, 2003; Jones, 2003; American Management Association, 2003; BoardSource and Independent Sector, 2003; Budak, 2003; Baker, 2005; Oxholm, 2005; Broude, 2006, Ostrower, 2007).

On the one hand, non-profit management and boards were expected to demand transparency and internal control along the lines of the new standards in the corporate sector. On the other hand, the donor communities were also to benefit from improved accountability and increased protection from failure of organizations' governance systems (Budak 2003).

Whereas recent research has shown that similar and comparable corporate governance practices were already implemented at a significant portion of sector organizations, further improvement of established systems and a need for increased accountability was supported by numerous sources (Jones, 2003; American Management Association, 2003; BoardSource and Independent Sector, 2003; Nezhina and Brudney, 2009).

The first actual legal embodiment of this debate is the California Non-Profit Integrity Act of 2004, specifically applying certain SOA provisions to non-profit entities (California Attorney General, 2004; Moerschbaecher, 2004; Ljung, 2005; Silk, 2005).

Beyond the progress on the legal side, there has developed a large body of best practice recommendations for US non-profit organizations based on the Act (Jones, 2003; Independent Sector, 2003; Everson, 2004; ABA Coordinating Committee on Nonprofit Governance, 2005; Jackson and Fogarty, 2006a; 2006b). 
Considering the impact SOA has had internationally on the corporate sector and the developments regarding SOA and the US non-profit sector, the Act can also be expected to have an effect on other industrialized countries with its mandates also becoming part of the development of non-profit corporate governance standards there.

\section{THE SOA FEATURES RELEVANT FOR CORPORATE GOVERNANCE IN THE GERMAN NPO SECTOR}

The Sarbanes-Oxley Act was intended for the for-profit sector addressing particular corporate governance shortcomings. Only two of its provisions apply directly to the non-profit sector. Further prescriptions of the Act have, in the meantime, been cast into new laws governing non-profit entities and still more features are numerously recommended to be adhered to voluntarily by non-profit organizations. For the purpose of this study, it is necessary to define those provisions of the Act which are of note to non-profit sector entities.

\section{Identification of the Prescribed and Recommended Provisions}

Researchers agree that there are two provisions of the Sarbanes-Oxley Act which also apply in the case of non-profit organizations (Budak, 2003; Hamel, 2003; Silk, 2004; Ostrower and Bobowick, 2006). One addresses record keeping, specifically document retention and destruction, which are covered in sections 802 and 1102 of the Act. Further, sections 806 and 1107 of the Act address the protection of individuals who provide incriminating information about their employer to the regulatory agencies. This is commonly referred to as "whistleblower protection".

Taking these into account and further summarizing the above cited recommendations, the following list of Sarbanes-Oxley provisions, as basis for the research at hand, can be drawn up:

1. Preparation and publication of financial statements

2. Existence of a board financial audit committee

3. Board financial audit committee members to have formal financial training

4. Commissioning of an annual external financial audit

5. Rotation of external financial auditor or lead audit partner at least every five years

6. Existence of a formal conflict of interest policy covering the organization's directors and executives

7. Existence of a formal process to handle employee complaints

8. Existence of a formal document retention/destruction policy

9. Prohibition of loans out of the organization's fund to its board members

\section{THE GERMAN NPO SECTOR}

The German NPO sector, as part of the overall economy, has grown and developed consistently through the decades and continues to display significant dynamics and adaptability (Bode, 2003). On the basis of the economic growth of the 1950s through 1970s, the extension of the welfare state in the 1960s and 1970s, in particular, had led to sustained growth for the organizations in the sector (Zimmer, 1999). Beyond the welfare sector and other traditional fields of activities, this period also saw the establishment of new organizations in new areas, among others, environmental protection, foreign aid, and international poverty alleviation. These became new drivers of growth and participation in the sector, as well as stimulants of organizational development, now also with an international aspect (Salamon and Anheier, 1997; Zimmer and Priller, 2004). By now, the non-profit sector has reached the threshold of 5\% of the entire employment of the German economy and it is, in comparison to the commercial and public sectors, the only part of the economy that has produced continuous increases in employment from 1960 through 1995. Its share of the Gross Domestic Product had reached 3.9\% by that time (Zimmer and Priller, 2004).

\section{Corporate Governance in the German Non-Profit Sector}

Corporate governance principles applicable to the non-profit sector in Germany are set down in a number of different laws and codes, but there is also a multitude of guidelines, recommendations or codes of conduct 
published for the sector. The corporate governance principles can thus be divided into statutory legal requirements and third-party guidelines. Whereas legal requirements are obviously mandatory for the organizations, third-party guidelines can be further divided into binding and non-binding.

\section{Legal Requirements}

There is no single body of law in Germany dealing with the non-profit sector corporate governance specifically and comprehensively. Rather, there are sections in a number of laws and codes addressing various aspects of non-profit governance (Anheier and Seibel, 1990). For example, basic requirements regarding registration and representation of associations are spelled out in the civil code ('Bürgerliches Gesetzbuch'). As Walz points out, regulation specific to non-profit financial accounting are almost completely missing. Here requirements set down for the corporate sector are interpreted as applicable for the non-profit sector as well (Walz, 2004). Yet other financial aspects are regulated in various sections of the tax code. This fragmented basis for non-profit corporate governance is resulting, in part, out of the long and winding historical development of the sector in Germany, as well as the particularly heterogeneous nature of the organizations (Anheier and Seibel, 1990, 2001; Bode and Evers, 2004; Kraus and Stegarescu, 2005).

\section{Binding Third-Party Guidelines}

Binding third-party guidelines are those that might arise out of organizational relationships; for example, a code of conduct issued by a national umbrella organization for its local or regional member organizations to which those have to subscribe (Deutsches Rotes Kreuz e.V., 1995; Diakonisches Werk der EKD, 2005). Non-conformity might lead to organizational sanctions for the non-compliant member organization. A significant portion of nonprofit sector organizations provide goods and most often services to state or municipal agencies or other governmental organizations which have outsourced to them the production of particular services. The state agencies or other organizations contracting these services from non-profit sector entities often mandate a wide range of rules and guidelines affecting the service provider. Examples are transparency of decision-making, document retention, or other procedures. Non-compliance with the guidelines can lead to ineligibility for future contracts or other measures (Landeswohlfahrtsverband Hessen, 2007). Other examples are guidelines issued by government agencies' adherence to which is made mandatory for organizations receiving certain types of aid or subsidies (Bundesministerium für wirtschaftliche Zusammenarbeit und Entwicklung, 2006).

\section{Non-Binding Third-party Guidelines}

Apart from the formal legal environment of the non-profit sector and the binding guidelines, a significant body of voluntary codes or best practice recommendations concerning the non-profit sector has developed in Germany with particularly pronounced dynamics in recent years (Brown, 2002; Hamel, 2003; Evers, 2004; Neumann, 2005; Bachert, 2006; Dawson and Dunn, 2006; Doll, 2006). In this particular area, the recent influence of international developments in non-profit corporate governance can be felt (Vogelsang and Buttkus, 2006; Deutsches Zentralinstitut für soziale Fragen, 2007b). New practices that have proven to be effective in other countries are introduced in the German non-profit sector. An example are efforts in data collection about sector organizations and a drive towards greater transparency of organizational information that is being introduced and modelled on similar activities in the US and UK (Buttkus, 2007).

\section{DEFINITION OF THE SET OF ORGANIZATIONAL CHARACTERISTICS FOR INVESTIGATION}

Following other research on organizations, particularly non-profits, the entities investigated were classified by a set of descriptive organizational characteristics. Those characteristics were then investigated concerning their association with the prevalence of the defined SOA type practices in the organizations.

Based upon the examples in the literature base, such as the studies by Salamon and Anheier (1997), Bies (2003), Wolfbauer (2006), Nah (2006), Crittenden and Crittenden (2000), Nezhina and Brudney (2009), as well as Ostrower and Bobowick (2006) and Ostrower (2007), the set of organisational characteristics for investigation in this research was assembled. Here, not only the choices made by these researchers were influential, but particularly 
the ways in how they have adapted sets of characteristics for the purpose of their specific research objectives. Of particular importance was the study by Ostrower and Bobowick (2006), which shares a very similar thrust with this research. On this basis, the following organizational characteristics were identified for use in this study:

1. Annual revenue, as a measure of organizational size, categorized as:

$\begin{array}{ll}\text { - } & \text { less than EUR } 100,000=\text { 'very small' } \\ \text { - } & \text { less than EUR 500,000 = 'small' } \\ \text { - } & \text { less than EUR 5,000,000 = 'intermediate' } \\ \text { - } & \text { less than EUR } 15,000,000=\text { 'big' } \\ \text { more than EUR } 15,000,00=\text { 'very big' }\end{array}$

2. Whether any board members have a professional background in any of the following fields:

- $\quad$ the organization's field of activity

- $\quad$ management

- law

- $\quad$ accounting

- $\quad$ other finance (e.g. banking, insurance, investment, etc.)

3. Whether the organization is part of an international network in any way

4. Age of the organization

5. The geographical scope of the activities of the organization:

- local

- regional

- national

- $\quad$ international

- other

6. The portion of the organization's funding that is based on donations

7. Whether members of the board of directors (BOD) are active in responsible positions in the corporate sector

\section{DEVELOPMENT OF THE RESEARCH QUESTION FOR THIS STUDY}

Assessing the relationship between SOA practices and organizational characteristics, the following research question and operational research objectives were defined to implement the study:

- What organizational characteristics of German non-profit organizations are most influential in determining potential compliance with the US Sarbanes-Oxley Act?

In further breaking down the research question, the specific research objectives were defined as:

- To identify the most significant organisational characteristics

- $\quad$ To rank the most significant organisational characteristics in terms of relative importance in determining potential compliance

- $\quad$ To evaluate the use of the ranking by stakeholders to determine potential compliance

- $\quad$ To evaluate the extent to which the most significant organizational characteristics could be used to increase potential compliance

\section{RESEARCH METHODOLOGY}

The Research Methodology of this study contained three individual approaches: 1) There was a mail questionnaire of German non-profit organizations, 2) further structured interviews with leaders of non-profit organizations, and 3) a review of related organizational documents. Other researchers focusing on the non-profit sector have also used a similar three-pronged methodology, sometimes applied in a step-by-step process (Gaid, 2007; Mellor, 2007; Pugh, 2007; Converse, 2008). This combined, mixed method approach is also subject of theoretical works on quantitative and qualitative research (Miles and Huberman, 1994; Easterby-Smith et al., 2002; Patton, 2002; Creswell and Plano Clark, 2007). 


\section{Mail Questionnaire}

The study was centred on a mail survey of German non-profit organizations gathering information about their individual organizational characteristics and their alignment with the defined provisions of the US SarbanesOxley Act. The design of the mail survey component is partly based on the recent study sponsored by the US Urban Institute which gathered data, among others, of the compliance of US non-profits and the organizational characteristics of those entities (Ostrower and Bobowick, 2006). For this research the questionnaire collects data regarding the SOA provisions and the organizational characteristics defined in the above Literature Review. The mail questionnaire of this research follows the 'Tailored Design Method' as developed by Dillman (Dillman, 1991; Salant and Dillman, 1994; Dillman, 2007). The questionnaire was pilot tested before the main data collection to ensure proper design.

In processing the questionnaire responses, the above defined nine SOA type corporate governance practices and the seven organizational characteristics were paired up and the gathered data analysed with the chi-square function to test the significance of any association between them. By way of the chi-square test, the association of all individual pairs of organizational characteristics and SOA features were tested. This statistical method for examining the association between variables is a recommended and proven research tool in social science (Roberts et al., 2003; Atteslander, 2006; Nezhina and Brudney, 2009; Hoggins-Blake, 2009). Additionally, the computation of the chi-square test is, in some cases, supplemented by the visual examination of the data tables to enrich the findings and to gather further information about the association of the variables.

Detailed information about the analysis of the survey data using these tools is presented at the end of this paper.

\section{Structured Interviews}

The survey was augmented and supported by structured interviews with a sub-sample of the organizations. A similar mixed method approach, involving a mail questionnaire and follow-up structured interviews, has been used by Bies in her study on the non-profit sector in Poland (Bies, 2002 and 2003). LaShaw (2007) conducted her recent work on non-profit accountability in the US, also employing both methods. Gaid (2007), as well, used interviews on her study of non-profit leadership and the same applies to Carman (2005). Generally, the application of the methods followed the work of Atteslander (2006) on research in the social science, Kromrey (2006) on empirical research, as well as Easterby-Smith et al. (2002). The addition of structured interviews to this study was further informed by Johnson and Onwuegbuzie (2004) and their particular endorsement of mixed method research. In general, the interviews focused, more than the questionnaire, on valuation or judgements, open questions and such, also addressing points-of-view. The structured interviews were also intended to increase the validity and generalizability of the findings of the mail survey.

The analysis of the structured interviews was meant to lead to the identification of the drivers of questionnaire results and to provide support for the overall results and conclusions of the study. For this purpose, the questions defined for the structured interviews addressed two main areas:

1. What are the reasons for the questionnaire results? Why are certain organizational characteristics more influential towards potential compliance with the main features of the Sarbanes-Oxley Act than others? Why are certain organizational characteristics not influential at all?

2. Are these results useful for the stakeholders? Why would certain groups of stakeholders find the results useful and other groups would not? Can the results be used for benchmarking? Why would the information about the most influential organizational characteristics be useful to increase potential compliance?

\section{Document Review}

Further, a document review of another sub-sample of the non-profit organizations was done. Here, documents of the organizations were reviewed, such as financial statements; articles of formation; by-laws; resolutions; publications; policies and manuals, if existing; the organization's code of ethics; programme materials; promotional materials for members or donors; field reports; and other documents relevant to the research question. 
The addition of such a document review has been successfully used in previous non-profit sector research. For example, Mellor (2007) augmented her study on nominating committees by a review of organizational documents. Other researchers used the analysis of organizational documents in combination with interviews of the non-profit organizations' leaders; for example, Gaid (2007) in her research involving an international poverty relief organization. The particular combination of survey, interviews and documentary review can be found, for example, in the research of Converse (2007) on communication among non-profit leaders and Pugh's (2008) study on nonprofit governance. Further, the use of organizational documents is also supported in secondary literature, such as Creswell (1998) and Mellor (2007). Miles and Huberman (1994) cite attention to organizational documents in their work on qualitative data analysis, as well as Creswell and Plano Clark (2007). Matching documentary data with interviews is emphasised by Patton as 'bringing together multiple perspectives' and thus enabling triangulation (Patton, 2002). This further method of data collection enabled triangulation of the findings and helped to ensure validity and reliability of the results.

For this purpose, the information regarding Sarbanes-Oxley type corporate governance practices prevalent in the organizations and regarding the organizational characteristics, as previously recorded in the questionnaires and structured interviews, were cross-checked with the organizations' materials. The particular focus of the document review was on those organizational characteristics that had been identified in the preceding analysis as having a significant association to the existence of SOA corporate governance features in the organizations. Further, regarding those organizations that provided information indicating they already follow SOA type corporate governance practices, their documents were examined with a view on corroborating that information.

\section{Sample Design and Details of the Data Collection Process}

As sample population for the study, the current holders of the seal of approval of the Deutsches Zentralinstitut für soziale Fragen (DZI) were selected. The DZI is a public trust first established in 1893 and today supported by the Senate of the City of Berlin, the Federal Ministry for Family, Senior Citizens, Women and Youth, the German Association of Chambers of Commerce, as well as by a number of non-profit sector umbrella organizations. The DZI is the main and most highly regarded accreditation body for donation soliciting organizations in Germany (Vallant, 2003). For the reporting period 2006/2007, 232 organizations where registered with the DZI and had received the award 'Donation-Seal - Verified and Recommended'. The survey was conducted in March and April of 2008.

For the purpose of the mail survey, the entire population of all registered organizations was included in the sample frame. The mail survey was pilot tested with a sub-sample of the population before application of the main study. For the second method of data collection, the structured interviews - a sub-sample of the respondents of the survey - were selected. The third part of the data collection was the document review of a further sub-sample of these organizations.

Whereas the mail survey led to positivist, quantitative results, the additional structured interviews and document review were intended to lead to supporting phenomenological, qualitative results, enriching and triangulating the research.

The data gathered through the mail questionnaire were analysed using the chi-square test, examining the associations between two groups of variables - the organizational characteristics and the existence of the defined SOA features. Since there has so far been no systematic research on the readiness of German non-profit organizations for the provisions of the Sarbanes-Oxley Act, this research was of an exploratory nature and sought to produce indicative results.

\section{RESEARCH RESULTS AND THEIR APPLICATION}

Of the 232 organizations registered with the DZI in 2006/2007, 159 returned a usable questionnaire, resulting in a response rate of $68.5 \%$. With 28 of the responding organizations, interviews were conducted. Further, 28 entities made organizational documents available for the documentary investigation. 
Based on the data analysis, the study resulted in the identification of an association of certain organizational characteristics with the existence of Sarbanes-Oxley type corporate governance practices in the organization. This association of characteristics and practices informs, as an indicative link, about a potential compliance of the organization. The identified characteristics in order of importance are:

1. The annual revenue of the organization - the higher, the greater the association

2. The age of the organization - the older, the greater the association

3. The existence of an international branch or sub-organizations structure

4. The organization's board members being active in the private sector

5. The organization having an international scope of activities

Further, the following organizational characteristics were found not to be indicative of an alignment with SOA-type corporate governance practices: The degree of funding out of donations and the board members having an applicable professional background.

\section{Representation of Selected Findings}

The following represent examples of the data concerning the link between organizational characteristics and the corporate governance practices. Figure 1 shows data concerning the annual revenue and commissioning of an annual external financial audit. Figure 2 represents data concerning the characteristics 'International Structure of the Organization' and 'Private Sector Activities of its Board Members' associated to corporate governance practices.

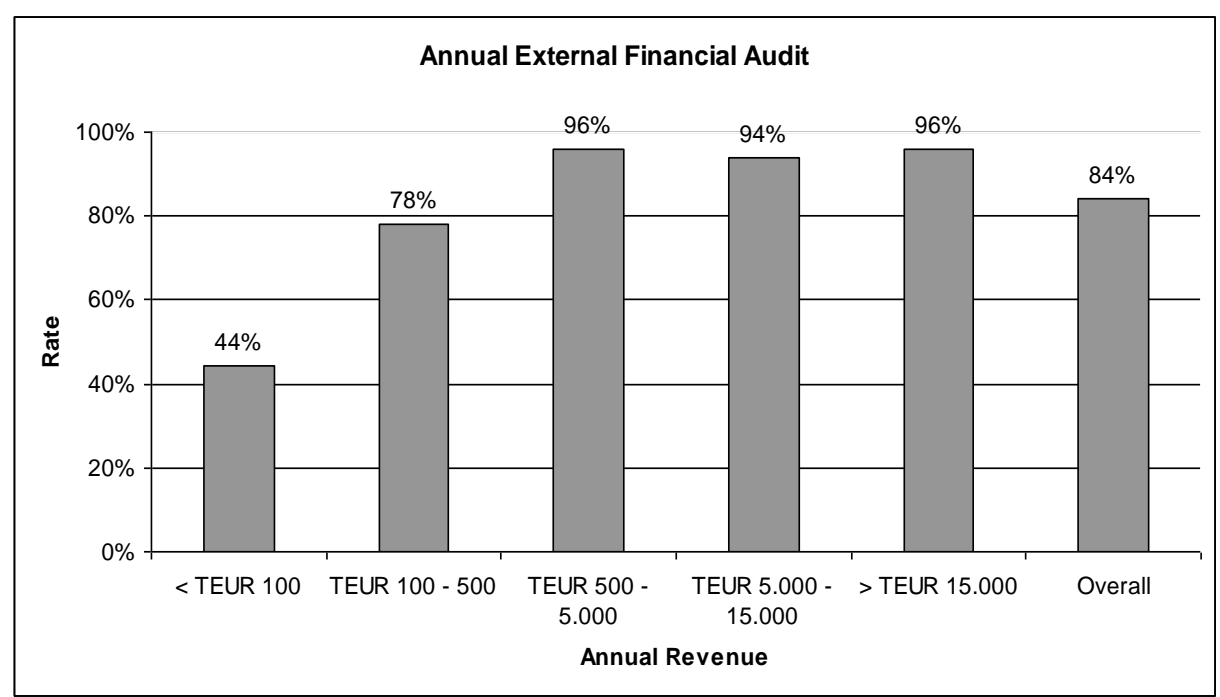

Figure 1: Example of Collected Data - Commissioning

of an Annual External Financial Audit in the Defined Categories of Annual Revenue 

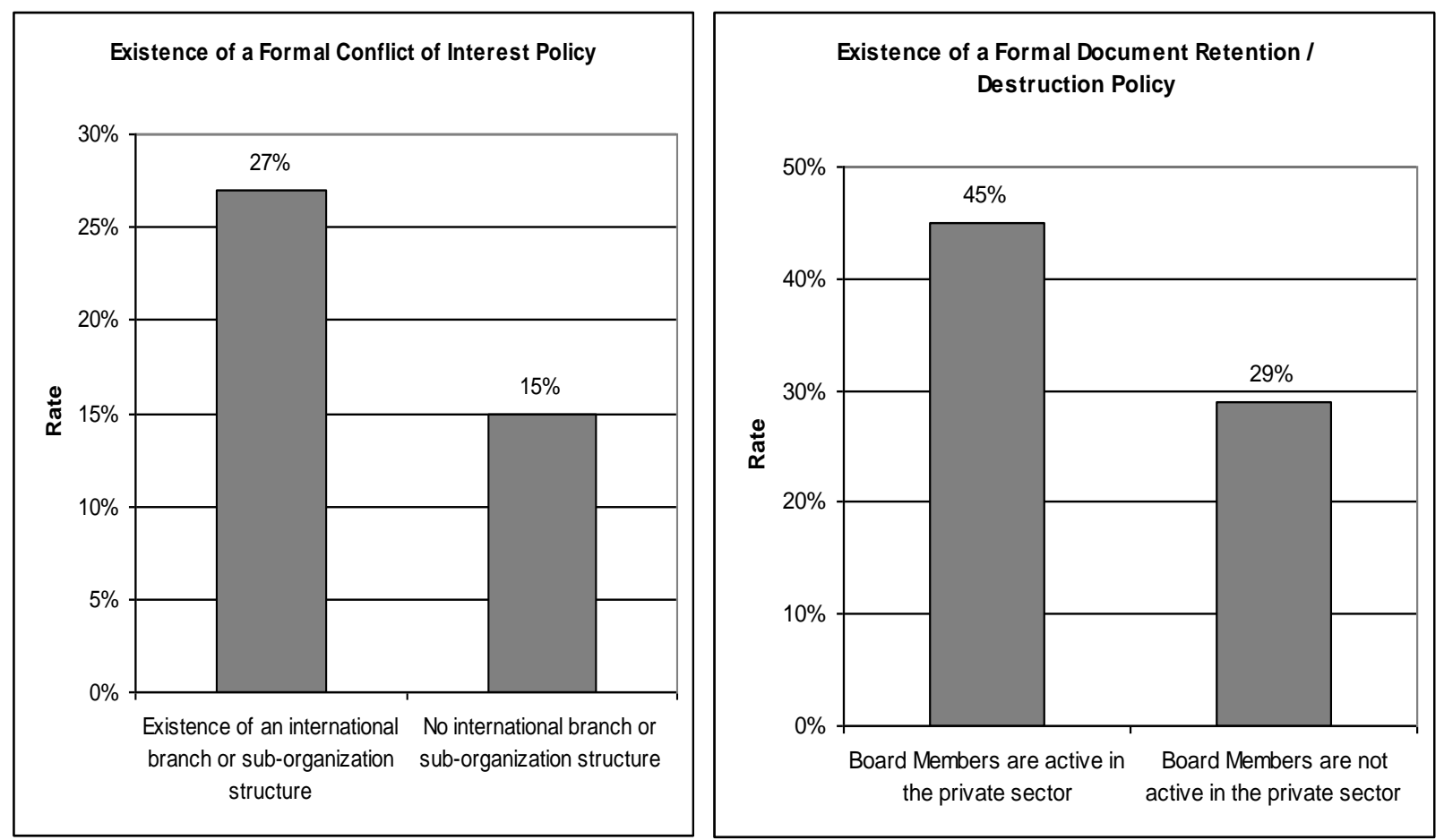

Figure 2: Examples of Collected Data - Existence of Policies in Association with an International Structure of the Organizations and Private Sector Activities of its Board Members

\section{Relationship to Other Recent Research}

These findings correspond closely with the research of Ostrower and Bobowick (2006), as well as Iyver and Watkins (2008), on the affect of SOA on non-profit corporate governance in the US. Nezhina and Brudney (2009) focus on the origins of the drivers in corporate governance change, but confirm the importance of the size of an organization as a significant determinant.

Utility of the Information on Organizational Characteristics' Influence to NPO Decision Makers, Lawmakers, Donors - Recommendations to Stakeholders

A further objective of the study was an assessment of the utility of the research results for certain groups of organizational stakeholders. Those were defined as NPO internal decision makers, lawmakers/regulators and donors/sponsors. Instrumental in this assessment was specifically the structured interview part of the research methodology. The results of the preceding mail questionnaire were briefly presented to the interview participants and their views on the perceived usefulness collected.

- $\quad$ Regarding the internal NPO decision-makers, to which group most of the interview participants themselves belonged, the majority of the responses indicated that this group of addressees would gain from this knowledge and benefit from the research results.

Use of research findings for this group would be through their application as a benchmarking tool. The NPO leaders can compare the readiness of their own organization to that of similar entities, described by their organizational characteristics, and assess a necessity for improvement in comparison to the organization's peers. The identified association between characteristics and SOA-type practices thereby served as an indicator of potential compliance of similar organizations. 
NPO decision-makers also benefit by using the knowledge about the association of organizational characteristics and potential compliance when working to improve corporate governance practices in their organization. Specifically, the information about the importance of the organization being part of an international network of organizations and the professional experience of board members relating to high potential compliance can be helpful in the development process.

- $\quad$ Regarding the utility of the results to regulators and lawmakers, the opinion of the interview participants was mixed. A slight majority of participants responded that the results would indeed be useful to this group of addressees.

Regulators and lawmakers can apply the research findings in assessing an impact of increased corporate governance regulation on certain groups of NPO relating to their already existing readiness.

Here, differentiation of regulatory initiatives concerning German non-profit organizations, depending on their organizational characteristics, is aided by the research findings. Specifically, the information about the influence of the annual revenue of an organization, as well as of its age, is of importance.

A practical example of such regulatory differentiation is the applicability of the California Non-profit Integrity Act only for organizations of an annual income of USD \$2,000,000 or more, exempting smaller organizations. Here, the impact, in terms of need for change, is likely to be greater than in lager organizations; but at the same time, this group possess fewer resources for the implementation of new requirements (California Attorney General, 2004).

- $\quad$ Regarding the usefulness of the research findings to donors and sponsors, the majority of the recorded responses were negative.

The study led to the conclusion that the findings are of only limited practical utility for most NPO donors and sponsors. Corporate governance matters were identified as commonly only of limited importance in the decision-making process of general donors.

Application of the research results in specific cases can be envisioned; for example, in larger scale professional sponsorship relationships where the industrial or business sponsors are familiar with and anticipate certain corporate governance practices in the supported organization. Here, the research results can provide guidance.

Beyond the defined concerned groups, the structured interviews led to the identification of additional groups of likely interested parties, which were mentioned by the participants. Among those were auditors and accountants specializing in services for the non-profit sector. Likewise, consultants working in the sector were mentioned as likely to benefit from the research results. Further, similar to the internal NPO decision-makers, interview participants pointed out that representatives of non-profit sector umbrella organizations were likely to be interested in this research.

Knowledge about the association between organizational characteristics and the existence of SOA-type practices can be utilized specific to these service providers' relationship to sector entities. Auditors and accountants can use the research findings to assess the potential strength of corporate governance systems relating to an organization's profile and relative to other organizations. Consultants can find use in identifying and evaluating needs for change in organizations. Further, representatives of NPO umbrella organizations can apply the research findings in communication with external addressees concerning sector corporate governance issues, their knowledge about the status having been further improved.

\section{Organizational Characteristics' Role in Increasing Potential Compliance with the US Sarbanes-Oxley Act}

A further objective set for this research was an examination whether those organizational characteristics, which were found to have an association with the existence of SOA-type practices in the organization, could become 
instrumental in increasing the potential compliance with the Act. The data for addressing this part of the research were mainly gathered in the structured interview segment of the research methodology. The responses from the interview participants to this question were mixed, with a slight majority assessing such an approach as useful or practical.

\section{OVERVIEW OF ALL RESULTS}

See Table 1 below for a complete overview of all results identifying the associations between organizational characteristics and the existence of Sarbanes-Oxley features and also showing those characteristics where no or only a small number of associations were found.

\section{CONCLUSION}

This paper presented the analysis of data concerning the preparedness of German non-profit organizations for compliance with the provisions of the Sarbanes-Oxley Act and those organizations' characteristics. The subject matter in regards to the Act's provisions, as well as the German non-profit sector were briefly described. Further, the research methodology encompassing data collection and statistical analysis were laid-out.

The results were presented in form of those characteristics identified as influential regarding the existence of Sarbanes-Oxley corporate governance features in those organizations. The paper also states how this knowledge can be used by various organizational stakeholders relating to matters of compliance. 


\section{Results}

\section{Existence of an Association between the Variables based on the Chi-square Test}

Organizational Characteristic:

\begin{tabular}{|c|c|c|c|c|c|c|c|}
\hline Sarbanes-Oxley Feature: & Annual Revenue & $\begin{array}{l}\text { BOD applicable } \\
\text { professional } \\
\text { background }\end{array}$ & $\begin{array}{l}\text { Existence of an } \\
\text { international } \\
\text { branch or sub- } \\
\text { organization } \\
\end{array}$ & \begin{tabular}{|l} 
Age of the \\
Organization
\end{tabular} & $\begin{array}{l}\text { International } \\
\text { Scope of } \\
\text { Activities }\end{array}$ & \begin{tabular}{|l|} 
Degree of \\
Donation \\
Funding
\end{tabular} & $\begin{array}{l}\text { Board Members } \\
\text { are active in the } \\
\text { private sector }\end{array}$ \\
\hline Preparation and publication of financial statements & YES & NO & NO & YES & NO & NO & YES \\
\hline Existence of a board financial audit committee & NO & NO & NO & YES & YES & NO & NO \\
\hline $\begin{array}{l}\text { Board financial audit committee members have formal } \\
\text { financial training }\end{array}$ & NO & NO & NO & NO & YES & NO & NO \\
\hline Commissioning of an annual external financial audit & YES & NO & YES & NO & YES & NO & NO \\
\hline $\begin{array}{l}\text { Rotation of external financial auditor or lead audit } \\
\text { partner in the last five years }\end{array}$ & YES & NO & YES & YES & NO & YES & YES \\
\hline $\begin{array}{l}\text { Existence of a formal conflict of interest policy covering } \\
\text { the organization's directors and executives }\end{array}$ & YES & NO & YES & YES & NO & NO & YES \\
\hline $\begin{array}{l}\text { Existence of a formal process to handle employee } \\
\text { complaints }\end{array}$ & YES & NO & YES & YES & NO & YES & NO \\
\hline $\begin{array}{l}\text { Existence of a formal Document Retention / Destruction } \\
\text { Policy }\end{array}$ & YES & NO & NO & NO & NO & NO & YES \\
\hline $\begin{array}{l}\text { Prohibition of loans out of the organization's funds to its } \\
\text { board members }\end{array}$ & NO & NO & NO & NO & NO & NO & NO \\
\hline Count & 6 & 0 & 4 & 5 & 3 & 2 & 4 \\
\hline
\end{tabular}

Table 1: Complete Overview of Results - Number of Associations between Organizational Characteristics and the Existence of Sarbanes-Oxley Features 


\section{AUTHOR INFORMATION}

Thomas Wilhelm Hasenpflug received his doctorate from Edinburgh Business School. His research centred on the growing non-profit sector in Germany. He also holds an M.B.A. and a M.Sc. from Edinburgh Business School, as well as a Dipl.-Betriebsw. (FH) from Fachhochschule Giessen, Germany. He is currently employed in the industry and preparing work on a textbook. E-mail: thomas_hasenpflug@yahoo.de

\section{REFERENCES}

1. ABA Coordinating Committee on Nonprofit Governance, 2005, Guide to Nonprofit Corporate Governance in the Wake of Sarbanes-Oxley, 1st edition, Chicago, ABA Publishing.

2. American Management Association, 2003, Should Privately Held Companies and Nonprofit Organizations Comply with the Sarbanes-Oxley Act?, http://www.amanet.org/press/amanews/SOX2003survey.htm, accessed 25 March 2007.

3. Anheier, H. K. and Seibel, W., 1990, The Third Sector: Comparative Studies of Nonprofit Organizations, 1st edition, New York, Walter de Gruyter.

4. Anheier, H. K. and Seibel, W., 2001, The Nonprofit Sector in Germanyl st edition, Manchester, Manchester University Press.

5. Atteslander, P., 2006, Methoden der empirischen Sozialforschung, 11th edition, Berlin, Erich Schmidt Verlag.

6. Bachert, R., 2006, Corporate Governance in Nonprofit-Unternehmen, Freiburg, Rudolf Haufe Verlag.

7. Baker, J., 2005, Nonprofits, Sarbanes-Oxley, and the States, http://www.guidestar.org/DisplayArticle.do?articleId=779, GuideStar, accessed 29 December 2008.

8. Bies, A. L., 2002, Self-Regulation in Poland's Non-Governmental Sector: Internal and External Dynamics, Mandatory and Discretionatory Approaches, Conference Paper, ISTR Fifth International Conference, July 2002, Cape Town, South Africa.

9. Bies, A. L., 2003, Nongovernmental Accountability in Poland: Mandatory versus Discretionary SelfRegulation, PhD Thesis, Minneapolis, University of Minnesota.

10. BoardSource and Independent Sector, 2003, The Sarbanes-Oxley Act and Implications for Nonprofit Organizations, http://www.boardsource.org/dl.asp?document_id=524, accessed 13 October 2007.

11. Bode, I., 2003, Flexible Response in Changing Environments: The German Third Sector Model in Transition, Nonprofit and Voluntary Sector Quarterly, Vol. 32, No. 2, pp. 190-210.

12. Bode, I. and Evers, A., 2004, From institutional fixation to entrepreneurial mobility? The German third sector and its contemporary challenges, in Evers, A. and Laville J.-L. (eds.), 2004, The Third Sector in Europe, 1st edition, Cheltenham, Edward Elgar Publishing Ltd.

13. Broude, P. D., 2006, The Impact of Sarbanes-Oxley on Private and Nonprofit Companies, Chicago, National Directors Institute.

14. Brown, W. A., 2002, Inclusive Governance Practices in Nonprofit Organizations and Implications for Practice, Nonprofit Management \& Leadership, Vol. 12, No. 4, pp. 369-385.

15. Budak, S., 2003, Why all the Fuss About the Sarbanes-Oxley Act?, http://www.usaid.gov/our_work/crosscutting_programs/private voluntary cooperation/conf budak.pdf, accessed 25 March 2007.

16. Bundesministerium für wirtschaftliche Zusammenarbeit und Entwicklung, 2006, Evaluierungskriterien für die deutsche bilaterale Entwicklungszusammenarbeit, http://www.bmz.de/de/zentrales_downloadarchiv/erfolg_und_kontrolle/evaluierungskriterien.pdf, accessed 4 October 2008.

17. Buttkus C., 2007, Mehr Transparenz gemeinnütziger Organisationen, http://guidestareurope.org/uploads/Almanach\%202007.pdf, accessed 9 October 2008.

18. Carman, J. G., 2005, Program Evaluation Use and Practice: A Study of Nonprofti Organizations in New York State, PhD Thesis, Albany, State University of New York.

19. California Attorney General, 2004, Nonprofit Integrity Act of 2004, Sacramento, California Department of Justice.

20. California Attorney General, 2005, Guide for Charities, http://ag.ca.gov/charities/publications/guide_for_charities.pdf, accessed 14 October 2007. 
21. Converse, D. L., 2008, The Role of Visuals in Effective Communication among Leaders in Nonprofit Organizations, Doctoral Dissertation, Seattle, Seattle University.

22. Creswell, J. W., 1998, Qualitative Inquiry and Research Design: Choosing Among Five Traditions, Thousand Oaks, Sage Publications.

23. Creswell, J. W. and Plano Clark, V. L., 2007, Designing and Conducting Mixed Methods Research, Thousand Oaks, Sage Publications.

24. Crittenden, W. F. and Crittenden V. L., 2000, Relationships between Organizational Characteristics and Strategic Planning Processes in Nonprofit Organizations, Journal of Managerial Issues, Vol. 12, Issue 2.

25. Dawson, I. and Dunn, A.2006, Governance Codes of Practice in the Not-for-Profit Sector, Corporate Governance, Vol. 14, No. 1, pp. 33-42.

26. Deutsches Rotes Kreuz e.V.1995, Leitsatz und Leitbild des Deutschen Roten Kreuzes, http://www.drk.de/direkte-weg/index.html, accessed 4 October 2008.

27. Deutsches Zentralinstitut für soziale Fragen, 2007b, EU fördert Datenbank für den gemeinnützigen Sektor, Press Release, http://www.dzi.de/PM26thJul.pdf, accessed 25 October 2007.

28. Diakonisches Werk der Evangelischen Kirche in Deutschland, 2005, Diakonischer Corporate Governance Kodex, http://www.diakonie-rwl.de/cms/media//pdf/service/infomaterial/Diakonie-CGK.pdf, accessed 4 October 2008.

29. Dillman, D. A., 1991, The Design and Administration of Mail Surveys, Annual Review of Sociology, Vol. 17, pp. 225-249.

30. Dillman, D. A., 2007, Mail and Internet Surveys: The Tailored Design Method, 2nd edition, New York, John Wiley \& Sons, Inc.

31. Doll, R.-P., 2006, Die Finanzierung von Nonprofit-Organisationen im Hinblick auf Basel II, Doctoral Dissertation, Bayreuth, Verlag P.C.O.

32. Easterby-Smith, M. and Thrope, R. and Lowe, A., 2002, Management Research, 2nd edition, London, Sage Publications.

33. Evers, A., 2004, Sektor im Spannungsfeld: Zur Theorie und Politik des Dritten Sektors, Working Paper, Münster, Institut für Politikwissenschaft, Westfälische Wilhelms-Universität.

34. Everson, M. W., 2004, Charitable Giving Problems and Best Practices, Written Statement of Hearing before the Committee on Finance of the United States Senate.

35. Gaid, B. F., 2007, A Case Study of Servant Leadership in the Coptic Orphans Support Associations, Doctoral Dissertation, Phoenix, University of Phoenix.

36. Hamel, W. W., 2003, What Corporate Governance Legislation Means To You: A guide to the implications of the Sarbanes-Oxley act for nonprofit organizations, Association Management, March 2003.

37. Heinz, P. A., 2003, Responding to the Sarbanes-Oxley Act of 2002: The Financial Reporting Practices of Nonprofits, Milwaukee, The Alliance for Children and Families.

38. Hoggins-Blake, R., 2009, Examining Non-Profit Post-Secondary Institutions' Voluntary Compliance with the Sarbanes-Oxley Act, Doctoral Dissertation, Prescott Valley, Northcentral University.

39. Iliev, P., 2007, The Effect of SOX Section 404 Compliance on Audit: Fees, Earnings Quality and Stock Prices, Working Paper, Pennsylvania State University.

40. Independent Sector, 2003, Learning from Sarbanes-Oxley: A checklist for Charities and Foundations, http://www.independentsector.org/PDFs/sarbanesoxley checklist.pdf, accessed 25 March 2007.

41. Iyer, V. M. and Watkins, A. L., 2008, Adoption of Sarbanes-Oxley Measures by Nonprofit Organizations: An Empirical Study, Accounting Horizons, Vol. 22, No. 3, pp. 255-277.

42. Jackson, P. M. and Fogarty, T. E., 2006, Sarbanes-Oxley and Nonprofit Management, 1st edition, Hoboken, Wiley \& Sons.

43. Jackson, P. M. and Fogarty, T. E., 2006, Sarbanes-Oxley for Nonprofit Boards, 1st edition, Hoboken, Wiley \& Sons.

44. Johnson, R. B. and Onwuegbuzie, A. J., 2004, Mixed Method Research: A Research Paradigm Whose Time Has Come, Educational Researcher, Vol. 33, No. 7, pp. 14-26.

45. Jones, J., 2003, N.Y.'s Attorney General Seeking To Apply Sarbanes-Oxley Act, http://www.nptimes.com/Mar03/npt2.html, accessed 25 March 2007.

46. Kraus, M. and Stegarescu, D., 2005, Non-Profit-Organisationen in Deutschland: Ansatzpunkte für eine Reform des Wohlfahrtsstaats, Working Paper, Mannheim, Zentrum für Europäische Wirtschaftsforschung $\mathrm{GmbH}$. 
47. Kromrey, H., 2006, Empirische Sozialforschung, 11th edition, Stuttgart, Lucius \& Lucius.

48. Landeswohlfahrtsverband Hessen, 2007, Richtlinien für das Begleitete Wohnen von behinderten Menschen in Familien, http://www.lwv-hessen.de/webcom/show_article.php/_c-329/nnr-122/i.html, accessed 6 December 2008.

49. LaShaw, M. N., 2007, The Adequacy of Church Financial Reporting in Eastern Washington, Doctoral Dissertation, Anderson, Indiana, Anderson University.

50. Litvak, K., 2007, The Effect of the Sarbanes-Oxley Act on Non-US Companies Cross-Listed in the US, Journal of Corporate Finance, Vol. 13, pp. 195-228.

51. Ljung, D., 2005, Eyeing nonprofits: the Charity Integrity Act \& other pending governance, accountability rules, California CPA, Jun 1, 2005.

52. Mellor, S. K., 2007, National, Professional Dental Associations: An Examination of Nominating Committee Processes, Doctoral Dissertation, Cincinnati, Union Institute \& University.

53. Menden, B. and Kralisch, R., 2008, SOX-Compliance Reloaded - außer Spesen nichts gewesen?, Zeitschrift für Controlling Management, Vol. 52, No. 4.

54. Miles, M. B. and Huberman, A. M., 1994, Qualitative Data Analysis, 2nd edition, Thousand Oaks, Sage Publications.

55. Moerschbaecher, L. S., 2004, Nonprofit Integrity Act Comes to California: Will Nation Follow?, http://www.pgdc.com/pgdc/article/2004/10/nonprofit-integrity-act-comes-california-will-nation-follow, accessed 29 December 2008.

56. Nah, S., 2006, Organizational Features, Media Publicity, and Website Use: A Case Study of Nonprofit Organizations in a Midwestern Community, PhD Thesis, Madison, University of Wisconsin.

57. Neumann, S., 2005, Non Profit Organisationen unter Druck, 1st edition, München, Rainer Hampp Verlag.

58. Nezhina, T. G. and Brudney, J. L., 2009, The Sarbanes-Oxley Act: More Bark Than Bite for Nonprofits, Nonprofit and Voluntary Sector Quarterly, Online First.

59. Ostrower, F., 2007, Nonprofit Governance in the United States: Findings on Performance and Accountability from the First National Representative Study, http://www.urban.org/UploadedPDF/411479_Nonprofit_Governance.pdf, accessed 3 October 2007.

60. Ostrower, F. and Bobowick, M. J., 2006, Nonprofit Governance and the Sarbanes-Oxley Act, http://www.urban.org/UploadedPDF/311363 nonprofit_governance.pdf, accessed 25 March 2007.

61. Oxholm, C., 2005, Sarbanes-Oxley in Higher Education: Bringing Corporate America's "Best Practices" to Academia, Journal of College and University Law, Vol. 31, No.2, pp. 351-376.

62. Patton, M. Q., 2002, Qualitative Research \& Evaluation Methods, 3rd edition, Thousand Oaks, Sage Publications.

63. Piotroski, J. D. and Srinivansan, S., 2008, Regulation and Bonding: The Sarbanes-Oxley Act and the Flow of International Listings, Working Paper, Stanford University Graduate School of Business and Harvard Business School.

64. Pugh, L. E., 2007, The Invisible Director: A Case Study of the Interpersoal Dynamics of Effective Nonprofit Governance from the Social Network Perspective, Doctoral Dissertation, Washington, The George Washington University.

65. Roberts, A.and Wallace, W. and Pfab, F., 2003, Introduction to Business Research 3: Research Methodology, Data Collection and Analysis, Results and Conclusions, Text Book, Edinburgh, Edinburgh Business School.

66. Romano, R., 2005, The Sarbanes-Oxley Act and the Making of Quack Corporate Governance, The Yale Law Journal, Vol. 114, No. 7, pp. 1521-1611.

67. Salamon, L. M. and Anheier, H. K., 1997, Defining The Nonprofit Sector: A cross-national analysis, 1st edition, Manchester, Manchester University Press.

68. Salant, S. and Dillman, D. A., 1994, How to conduct your own survey, New York, John Wiley \& Sons, Inc.

69. Schuerman, M., 2004, On the Board Sarbanes-Oxymoron, http://www.worth.com/Editorial/MoneyMeaning/Philanthropy/On-the-Board-Sarbanes-Oxymoron-2.asp, accessed 4 October 2007.

70. Shirley, J., 2004, International Law and the Ramifications of the Sarbanes-Oxley Act of 2002, Boston College International \& Comparative Law Review, Vol. 27, No. 2, pp. 501-528.

71. Silk, T., 2004, Ten Emerging Principles of Governance of Nonprofit Corporations and Guides to a Safe Harbor, The International Journal of Not-for-Profit Law, Vol. 7, Issue 1. 
72. Silk, T., 2005, Rational Exuberance: An Exploration of the Adaptation by California's Charitable Sector to Changing Governance Standards - Notes from the Field, The International Journal of Not-for-Profit Law, Vol. 8, Issue 1.

73. United States Congress, 2002, American Competitiveness And Corporate Accountability Act of 2002, 107th Congress of the United States of America, Washington, Government Printing Office.

74. Vallant, S., 2003, Möglichkeiten und Grenzen von Spendengütesiegeln, Master Thesis, Vienna, Österreichische Forschungsstiftung für Entwicklungshilfe (ÖFSE).

75. Vogelsang, M. and Buttkus, C., 2006, Aufbau einer bundesweiten Online-Datenbank für den gemeinnützigen Sektor, Working Paper, 6. Hamburger Tage des Stiftungs- und Non-Profit-Rechts.

76. von der Crone, H. C. and Roth, K., 2003, Der Sarbanes-Oxley Act und seine extraterritoriale Bedeutung, Aktuelle juristische Praxis, Vol. 12, No. 2, pp. 131-140.

77. Walz, W. R., 2004, Rechnungslegung und Transparenz im Dritten Sektor, 1st edition, Köln, Carl Heymanns Verlag.

78. Wolfbauer, J., 2006, Die Strategische Rolle von Governance-Organen in Nonprofit Organisationen, Doctoral Dissertation, Rotterdam, Erasmus Universiteit.

79. Zhang, I. X., 2005, Economic Consequences of the Sarbanes-Oxley Act of 2002, Working Paper, Rochester, New York, University of Rochester.

80. Zimmer, A., 1999, Corporatism Revisited - The Legacy of History and the German Nonprofit-Sector, Voluntas, Vol. 10, No. 1, 37-49.

81. Zimmer, A. and Priller, E., 2004, Gemeinnützige Organisationen im gesellschaftlichen Wandel, 1st edition, Wiesbaden, Verlag für Sozialwissenschaften. 